\title{
Старообрядческие монастыри «енисейского меридиана» в XX веке: истоки, традиции и современное состояние
}

\author{
Алена А. Стороженко \\ Тувинский государственный университет, \\ Российская Федерация
}

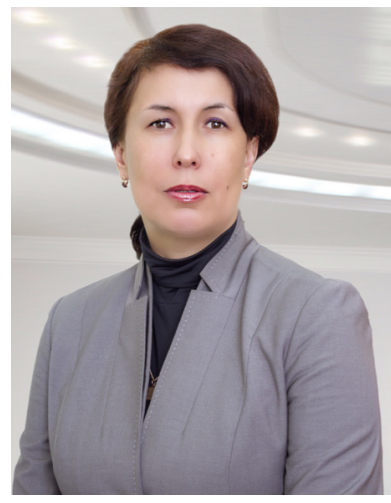

В статье анализируется роль старообрядческих монастырей в процессе складывания единого конфессионального пространства современных часовенных Красноярского края и Тувы. Исследуются направления и мотивы их миграционных маршрутов, особенности внутренней конфессиональной жизни и устройства старообрядческих монастырей как конфессиональных и хозяйственных цзентров. Источниковой базой исследования стали воспоминания очевидцев событий и свидетельства информантов, а также документы из Государственного архива Республики Тыва.

Делается краткий обзор расселения старообрядиев в ХХ в. на территориях южной Сибири. Рассматриваются традиции устроения енисейских старообрядческих монастырей в ХХ веке.

Конфессиональное пространство часовенных не знает других грании, кроме сакральных. Собор там, где есть «свои» люди, родственники, единоверцы. Несмотря на кажущуюся разрозненность и удаленность их поселений, связи между ними никогда не разрываются. Дубчесские монастыри не переставали быть духовными центрами не только для округи, но и всего социума часовенных в мире, включая тувинских.

Потребность у часовенных в сохранении общего конфессионального пространства, сохранившееся совместное соборное обсуждение вызовов времени, поддержка чистоты конфессиональных брачных связей и, как следствие, сохранение семьи, общины, заинтересованной в существовании скитов как идеологических и духовных центров - все это позволяет надеяться на дальнейшее развитие скитской традиции и даже, возможно, возрождение ее в Туве в обозримом будущем.

Ключевые слова: Тува; история Тувы; Красноярский край; енисейский меридиан; старообрядчество; история старообрядчества; Дубчес; часовенные; монастырь; скит; конфессиональное пространство

"Выполнено при поддержке РФФИ (проект «"Енисейский меридиан” старообрядчества: сохранение и развитие традиции в условиях таёжных скитов и деревень», грант № 18-09-00723).

\section{Для цитирования:}

Стороженко А. А. Старообрядческие монастыри «енисейского меридиана» в XX веке: истоки, традиции и современное состояние [Электронный ресурс] // Новые исследования Тувы. 2019, № 1. URL: https://nit.tuva.asia/nit/article/view/826 (дата обращения: дд.мм.гг.). DOI: 10.25178/nit.2019.1.1

Стороженко Алена Александровна - кандидат исторических наук, доцент кафедры отечественной истории Тувинского государственного университета. Адрес: 667000, Россия, г. Кызыл, ул. Ленина, д. 36, каб. 116а. Тел.: +7 (394) 222-238-38. Эл. адрес: alstorozhenko@yandex.ru ORCID: 0000-0001-9986-8966

Storozhenko Alena Aleksandrovna, Candidate of History, Associate Professor, Department of Russian History, Tuvan State University. Postal address: 36 Lenin St., Kyzyl, 667000 Russia. Tel.: +7 (394) 222-238-38. E- mail: alstorozhenko@ yandex.ru ORCID: 0000-0001-9986-8966 


\title{
Old Belief monasteries of the «Yenisei meridian» in the 20th century: origins, traditions and current state"
}

\author{
Alena A. Storozhenko \\ Tuvan State University, Russian Federation
}

The article analyzes the role of Old Belief monasteries in the rise of a universal confessional space of contemporary Chasovennye («chapel-goers» or "chapel people", a non-priestly faction among Old Believers) in the Krasnoyarsk oblast and Tuva. Also explored are the trends and motives of their migration routes, peculiarities of the religious life within their communities and the structure of Old Belief monasteries as religious and economic centers. The source base of the study includes eyewitnesses' recollections and testimonies from other informants, as well as documents from the state archive of the Republic of Tuva.

The article is complemented with a brief review of the settlement of Old Believers throughout southern Siberia in the 20th century. The traditions of spiritual and economic life in Old Belief monasteries along the Yenisei in the 20th century receive special treatment.

The confessional space of the Chasovennye knows no other boundaries than the sacred. The Council (sobor) appears where the community's "own" people are, such as relatives or co-religionists. Despite the seeming fragmentation and remoteness of their settlements, the ties between them never break. Dubches monasteries never ceased to be spiritual centers for both its immediate neighborhood and the whole community of the Chasovennye in the world, including Tuva.

The need for the community to preserve the common confessional space, the still-practiced joint discussion of the challenges of the time, the support for the purity of marriage ties and, as a consequence, the preservation of the family and the community in need of the monasteries as its ideological and spiritual centers - all of these hold out our hope in the future of the skete tradition and even, perhaps, in its revival in Tuva in the foreseeable future.

Keywords: Tuva; Tuvan history; Krasnoyarsk oblast; 'Yenisei meridian'; Old Belief; Old Believers' history; Dubches; Chasovennye; monastery; skete; confessional space

"Supported by RFBR, project no18-09-00723 "The Yenisei Meridian" of the old believers: the preservation and development of traditions in taiga monasteries and villages.

\section{Введение}

Старообрядцы появились в Сибири практически сразу же после раскола православной церкви в XVII веке и быстро стали явлением повсеместным, распространившись почти по всей территории Сибири, как западной, так и восточной.

Достаточный миграционный потенциал им позволил стать тем маховым механизмом, который продвинул русскую землепроходческую колонизацию в самые отдаленные сибирские окраины. Уже в XVIII в. в зонах первичного освоения формируется система старообрядческих скитов и по мере «обрастания» крестьянскими заимками, постепенно превращающимися в деревни, продвигается в новый очаг колонизации (Мамсик, 1989: 30). Эта тенденция четко прослеживается в Зауралье, на Алтае, в Туве и является преобладающей вплоть до начала 
XX века. Старообрядческие скиты и монастыри постепенно продвигаются вместе с крестьянскими поселениями по всей Сибири и за границу России, в частности в Туву, до 1944 г. являвшейся самостоятельным государством.

Целью настоящей статьи является выявление роли старообрядческих монастырей в процессе складывания единого конфессионального пространства современных часовенных в XXI веке. Исследуются направления и мотивы их миграционных маршрутов, особенности внутренней конфессиональной жизни и устройства старообрядческих монастырей как конфессиональных и хозяйственных центров. Территориально «енисейский меридиан», включающий в себя Красноярский край и Туву, определен как достаточная исследовательская площадка, учитывая генетическое единство конфессиональных корней насельников скитов на всей его протяженности.

В основу источниковой базы статьи легли воспоминания очевидцев событий и свидетельства информантов, имеющих достаточный жизненный опыт, чья осведомленность, включенность в конфессиональный социум обладают несомненным эвристическим потенциалом, вызывают доверие. Их подробные воспоминания, записанные автором в ходе полевых сезонов 2016, 2017 и 2018 гг. в Верховьях Малого Енисея, позволяют глубже понять особенности конфессионального поведения старообрядцев, уточнить особенности скитской жизни послушниц и монахинь старообрядческих скитов «енисейского меридиана» и частично восстановить судьбы скитников после разгрома 1951 г. В фонде 123 Государственного архива Республики Тыва отложились «Посемейные списки русского населения Урянхайского края», прошения о заселении, позволившие автору реконструировать поселенческую структуру Тувы во второй половине XIX - начале XX вв., определить сроки и размещение населенных пунктов, основанных старообрядцами, уточнить хронологические рамки процесса заселения.

\section{Обзор научной литературы}

Изучение миграционного движения населения есть изучение истории края и всегда было в центре внимания исследователей. Несмотря на превалировавший в советской историографии макроподход к изучению переселения и хозяйственного освоения Сибири, прежде всего как явлению социально-экономического плана, уже в 1989 г. в трудах Т. С. Мамсик было апробировано изучение микропроцессов хозяйственного, социально-экономического, культурно-исторического планов (Мамсик, 1989: 3-4) именно на примере скитской организации старообрядцев.

Благодаря многолетним исследованиям Н. Н. Покровского и Н. Д. Зольниковой заложена методологическая основа изучения и в целом рассмотрены процессы складывания сети старообрядческих скитов и поселений в Красноярском крае и в Туве в середине XX века (Покровский, 1991; Покровский, 1992). На основе анализа Урало-Сибирского патерика ${ }^{1}$ восстановлены основные направления миграций уральских часовенных и их скитов в конце XIX века, приведшие их сначала в 1892 году на р. Чулым, а затем в 1917 г. - в Колыванскую тайгу на границу современных Томской и Новосибирской областей (Зольникова, 1998: 176) и одновременно - в Туву, куда переместился осколок скита о. Нифонта, во главе с о. Игнатием (Покровский, Зольникова, 2002: 29).

При этом практически не раскрытыми остались особенности скитской жизни насельниц и монахинь старообрядческих скитов «енисейского меридиана» и совершенно не реконструирована дальнейшая история обитателей дубчесских скитов после разгрома 1951 г. Хотя эта «дубчесская выгонка» по масштабам, исторической значимости достойна такого же подробного научного осмысления как знаменитая ветковская выгонка 1764 г.

1 Урало-Сибирский патерик - обширное историко-агиографическое сочинение, созданное в конце 1940 -х начале 1990-х гг. в крупнейшем на востоке России старообрядческом часовенном согласии. Его основу составили сочинения староверов XVIII-XIX вв. по истории конфессии, записи устных преданий, авторские тексты составителей патерика - крестьянских писателей (Журавель, 2013: 58). 
Позитивистская методология изучения переселений, в том числе конфессиональных, ограничивавшаяся анализом факторов и причин переселения, их показателей и условий, на современном этапе не раскрывает историю «человека культурного». Конфессиональная миграция как особый вид пространственного перемещения населения нашла свое отражение в трудах Е. Е. Дутчак. Очевидно, что назрела необходимость смены или как минимум смены уточнения категориального аппарата и создания модели конфессиональной миграции, которая бы системно представляла субъективные предпосылки и объективные условия, позволявшие человеку сначала оставить знакомые и родные места, а потом считать свое переселение состоявшимся и ненапрасным (Дутчак, 2007: 23; 2006: 81-94).

Начатое детальное и подробное изучение истории старообрядчества в Туве в последнее время (Татаринцева, 2006; Татаринцева, Стороженко, 2015; Стороженко, 2015), ряд совершенных комплексных экспедиций, вместе с тем, вызвали к жизни ряд вопросов, связанных с пониманием особенностей его внутренней конфессиональной жизни. Свидетельств или архивных документов, проливающих свет на эту проблему, к настоящему времени не обнаружено, в связи с чем приходится использовать сравнительный метод, совмещенный с методом реконструкции.

Особенно нуждаются в пересмотре и уточнении вопросы, связанные с перемещением конфессиональных центров, населения с ними связанного, формирования сакрального ландшафта. Такими авторитетными центрами стали, и в Туве, и в Сибири в целом старообрядческие скиты часовенного согласия, история которых насчитывает более ста лет (Стороженко, Татаринцева, 2016: 95).

\section{Традиционное конфессиональное поведение старообрядцев часовенных}

Исторически конфессиональная жизнь старообрядцев часовенного согласия осуществлялась и в мирском, и в монастырском вариантах. При этом формой монастырской организации были небольшие пустыни, для старообрядческой округи выполнявшие роль идеологических и культурных центров, приютов для вдов, сирот и стариков (Зольникова, 1998: 176).

Территориально в Туве скиты были расположены в долине Малого Енисея, выше по его течению начиная от места впадения в него р. Ужеп. Устья большинства всех мелких речек и ручьев, впадающих в Малый Енисей вплоть до так называемой «стрелки», там, где сливаются Балыктыг-Хем и Кызыл-Хем, стали тем удобным местом, где старообрядцы-часовенные основали еще в первой половине XX века немало пустынь и скитов. Одна из самых знаменитых скитниц - матушка Надежда (Михайлова) с сестрами матушкой Анафролией и матушкой Досифеей жили на Чендрактах. Немало отшельнических поселений было на Янзелях, Окчарах, Унжее, Мае, Мостах (Стороженко, Татаринцева, 2016: 95).

На рубеже 1930-1940-х годов в бассейне реки Дубчес (левого притока Енисея) на территории Красноярского края и соседней Томской области в результате многолетнего переселения уральских и западносибирских крестьян и скитников образовалась сеть мирских поселков и монастырей старообрядцев часовенного согласия. Глухие, таежные места стали удобным местом благодаря малонаселенности (даже коренное население - остяки здесь почти не проживали), отсутствию коллективизации, труднодоступности для представителей власти и вообще любых чужаков. До марта 1951 года здесь появлялись только редкие партии геологов, охотников. Операция по уничтожению дубчесских монастырей была, очевидно, тщательно спланирована, собраны сведения, нашлись и предатели - проводники, согласившиеся провести вооруженный отряд к месту расположения монастырей. Примечательно, что имена предателей известны участникам событий. История разгрома подробно восстановлена в трудах сибирских историков и здесь на ней останавливаться не стоит (Зольникова, 1998; Покровский, Зольникова, 2002).

После разгрома арестованные монахи, монахини и некоторые бельцы были осуждены и отправлены в лагеря ГУЛАГа в 1952 г. Некоторые из уцелевших после заключения и вывозки 
на плотах из монастырей не сразу вернулись обратно, а 10 отпущенных в Ворогово послушниц остались в миру. Все вышли замуж, но вырастив детей, некоторые вернулись обратно и «накрылись». Скорее всего, к 1990 г. таких случаев было четыре. «На верхней обложке, находящейся у А. Г. Мурачева рукописи «Истории о Дупческих скитах», школьной тетрадке в «Добавлением», внизу рукой автора приписано: «...Ети были отпущены: Клавдия, Анфиса, Иустина, Алевтина, Евдокия, Манефа, Евстолия, Кира, Федосья, Домна, Ирина, Анфиса, Анна (4 матери накрытые)» (Мурачев, 1999: 287). Оставшиеся в «миру» сумели до конца жизни сохранить связи с монастырями. Испытания, выпавшие на их долю, не только не оттолкнули, но и укрепили в вере, «...только ценное и осталось, что все верующие по сей день» (там же: 287).

Среди отпущенных была ныне живущая в одном из старообрядческих поселков верховьев Малого Енисея в Туве Клавдия Ивановна, ставшая свидетельницей и участницей трагических переломных событий в истории сибирского старообрядчества середины XX столетия. Всю свою сознательную жизнь она прожила в старообрядческом селе в верховьях Малого Енисея, в Туве. Приехала в 1950-е гг. в дер. Бельбей Каа-Хемского района вместе с матерью, мужа нашла почти сразу же. Была снохой старообрядческого наставника в верховье, родила троих детей. На склоне лет попыталась жить в монастыре в Верховье Малого Енисея, но не смогла выдержать монашеского устава и через несколько месяцев вернулась обратно в поселок.

Скиты, будучи колонизационными форпостами, в своем постоянном перемещении не ставили задачу хозяйственного освоения территории, скорее это становилось следствием. Ведь бегство само по себе еще не являлось решающим фактором успешной колонизации (Мамсик, 1989: 26). В массе своей скитники были скорее малоимущими и не могли без помощи крестьян и промысловиков обеспечивать себя в полной мере. В условиях гонений скиты постоянно перемещались и само их существование «было тесно связано с мирской колонизацией, крестьянским побегом» (там же: 176-177).

Именно так возник монастырь матушки Флены, в который ушла малолетняя Клавдия Ивановна и где сформировалось ее конфессиональное сознание. Матушка Флина (по упоминанию в Патерике) или Флена (по упоминанию Клавдии Ивановны), в миру Шабаршина Татьяна Кондратьевна, из верхотурских крестьян. После гибели мужа на фронте и смерти ребенка в 1918 г. уходит в нижнетагильский скит матушки Александры и матушки Елисаветы на р. Лае. После смерти матушки Елисаветы в алтайском Ашпанаке «бысть во обители нестроение, а потом и конечное разорение, разошлись кто куда.... Мать Флина с матерью Авсиянией уехали на Урал и там получили от некоего отца благословление на управление сестрами» (Урало-Сибирский патерик, 2014: 174). Около 1937 г., переехав в Томскую тайгу на заимку Кустовых, переместилась с ними на Безымянку, где и стала игуменьей примерно в 1938-1939 гг. (там же: 320).

Клавдия Ивановна была в числе тех, кто оказался в скиту матушки Флины в его бытность на Безымянке.

По ее словам, родилась она в Пермской губернии, «в с. Малая Уса, Усинского района, на Урале. Переехали в Томскую область. Мне было примерно 4 года. Начались притеснения, поэтому поехали от безбожной власти. Не давали молиться, креститься» (Полевые материалы автора - далее ПМА, 2016 г.).

Если Клавдия Ивановна родилась в 1926 г., значит, семья ее отца Сальникова и матери Кобелевой Агафьи Александровны переехала в Сибирь примерно в 1930 г., скорее всего спасаясь от коллективизации. Отец умер, когда матери было всего 38 лет. Жили сначала в п. Сушняки Тегульдетского района Томской области, пока не начались аресты. В семье было 9 детей (пятеро умерли, остались четыре дочери) и из них две ушли в монастырь - Клавдия и Иустина.

«В 12 лет я сама ушла в монастырь. Кмаминым знакомым. В школу неохота было ходить. Одну зиму успела походить в школу. Родители научили читать божественные книжки» (ПМА, 2016 г.).

Основываясь на материалах судебно-следственного дела 1951 г., Н. Д. Зольникова описала аналогичный случай с Елизаветой Глуховой (будущей матушкой Еванфией), племянницей 
того самого И. И. Кустова, что пригласил на свою заимку на р. Чарус матушку Флену, приехавшую с Урала искать возможности возвращения к монашеской жизни. Ее мать «не желавшая, чтобы дочь посещала безбожную советскую школу, ходила в кино и проч., предпочла видеть ее монахиней и отправила в монастырь на р. Чарус» (Зольникова, 1998: 181). С малолетства дети жили в скитах, иногда несколько лет. Они «напитывались» духом веры, закрепляли основы полученного в семье конфессионального поведения. Авторитет монахинь, красота богослужения, даже внешнее одеяние - все привлекало молодых: «...как оне оденут чин в праздник, тока смотреть на них» (ПМА, 2018 г.).

Вероятнее всего, у Клавдии Ивановны обстоятельства ухода были схожими - и среда, и мотивы, - все располагало к этому. И на Дубчес (духовный центр старообрядцев-беспоповцев часовенного согласия на реке Дубчес) Клавдия Ивановна шла вместе с сестрами и братом Глуховыми - Елизаветой (будущая матушка Еванфия), Татьяной (будущая матушка Трифена) и Макарием (будущий отец Михаил). Также с ними еще был один мирский крестьянин Онисим Катаев.

Мотивация дальнейшего перемещения монастыря на Дубчес проста и в тоже время показательна сила авторитета монахов над послушниками:

«Молодых заберут, надо уходить дальше в тайгу и наши отцы, матушки отправили нас молодых. Это не родители, это из монастыря меня отправили. Тут уж не родители руководили нами» (ПМА, 2018 г.).

Уход в монастырь-скит не был в Верховье явлением чем-то необычным. Напротив, это было заветное желание многих «мирских», хотя далеко не всегда осуществимое. По убеждению старообрядцев, в монахи можно уходить только в том случае, «когда в мирской жизни тебя уже ничего не держит». Как говорят они сами, «в монашки можно пойти только тогда, когда ты свободна от мирских обязанностей, когда тобой никто не нуждается и ты ни о ком не думаешь» (Стороженко, Татаринцева, 2016: 95).

Воспоминания Клавдии Ивановны сходятся с текстом патерика, что скит матушки Флены до 1945 г. был на Безымянке (Урало-Сибирский патерик, 2014: 174). Она подтверждает:

«Сначала я жила в монастыре в Томской области, рядом с Енисейском. Там близко мир. Людей вывозили... Не все сразу на Дубчесе. Здесь по Безымянке мы жили первый год на етих, на свободных местах. Хоть чо где бери. Там я уже забыла, сколь годов мы жили. Ну не больше годов, может 6-7» (ПМА, 2016 г.).

Трудно добирались на Дубчес. Бывшая послушница вспоминает:

«Шли мы туда на Дубчес молодые. Нас шесть человек шло, потому что по реке нельзя было. Стояли там какие-то рабочие люди, лес плавили, что стража была, на Дубчес по реке не проедешь. А нас молодых отправили. Нас вот троих, три мужчины и нас трех девушек женщин. Пешком мы шли шесть недель шли, а он, путеводитель Александр Григорьевич заблудился по рекам, по карте почему-то ошибился. Если бы он не ошибился, мы бы быстрее пришли, а мы долго неправильно шли и вот шесть недель шли по тайге. С июня по август» (ПМА, 2016 г.).

Путь лежал с Сыма на Дубчес, лодки для переправы делали на месте. Добрались до заимки Иерона Алексеевича Потанина, а дальше уже путь по тайге стал понятен. Эта заимка была одним из тех форпостов, которые служили скитам «связниками» с внешним миром: доставляли едущих в скиты, провожали уезжавших оттуда, сопровождали грузы (Зольникова, 1998: 188). Вероятно, переселялись по несколько партий.

По приезду на Дубчес послушников определили в скит матушки Еванфии (Осиповой). Жившая там матушка Максимила была как родная мать, учила, наставляла. Через год приехала матушка Флина и Клавдия Ивановна с сестрами Глуховыми перешла к ней. Начавшаяся скитская жизнь, обусловленная религиозным воспитанием и сознанием, по ее признанию не была легкой, но и другой модели жизнеустройства молодая девушка не представляла. 
Жизнь в пустыне требует подвижничества и каждодневного труда, а для мирских - это пример для подражания, поэтому многие глубоко верующие староверы стремятся следовать правилам монашеской жизни, не будучи монахами. Отсюда и популярность одиноких отшельнических поселений. Подобные заимки - одиночные или малодворные поселения в таежной глуши продолжают существовать и в наши дни в верховьях Малого Енисея (Стороженко, Татаринцева, 2016: 96).

\section{Традищии устроения енисейских старообрядческих монастырей в XX веке}

Старообрядческие скиты и монастыри как модели пустынножительного бытия фиксируются в сибирском делопроизводстве еще в XVIII веке, являя собой пример не только развития христианской иноческой традиции, но и создания совершенно особой, фронтирной, модели жизнеустройства (Мамсик, 1989: 31; Дутчак, 2011: 951). В ходе освоения новых территорий, старообрядческая эсхатология стала смысловым ядром пустынножительства как культурной ценности и колонизации как конфессионально-обоснованного вида деятельности, обеспечивала осмысление происходящего и отбор актуальных поведенческих образцов (Дутчак, 2011: 951).

Верховье Малого Енисея как наиболее подходящее место для устройства и мирских поселений и монастырей было известно старообрядцам еще в конце XIX века. Достоверно известно, что в 60-е годы XIX века мирские заимки, хоть и сезонные, усинских староверов здесь уже существовали (ГА РТ. Ф. 123, оп. 2. д. 4; Стороженко, 2004: 16). Места по Дубчесу и другим притокам Енисея (Подкаменной и Нижней Тунгуске) и дальше до Северного Ледовитого океана также давно были освоены и не только староверами. Попыток заселиться долгое время здесь практически не было, учитывая труднодоступность и удаленность от основных транспортных магистралей, которыми в этом суровом краю служили реки и речушки. Собственно дорог здесь нет и до сих пор, что и позволяет староверам сохранять свои поселения конфессионально нетронутыми. Разведки шли долго, староверы с помощью крестьян-охотников и промысловиков собирали сведения о возможности основать поселения, скиты, монастыри. Переселялись с большими трудностями, подготавливали места для женских скитов, которые самостоятельно не смогли бы выжить, особенно на первых порах. Приходилось расчищать землю, сначала для построек, потом под пашню, корчевать и пилить лес, строить кельи, хозяйственные постройки - все это вручную.

Клавдия Ивановна отмечает: «Мы пришли на готовое...», монастыри были уже построены (ПМА, 2016 г.).

«И тут были три обители на разных местах на притоках Дупчеса с правой стороны: на Малом Тогульчесе обитель матери Тавифы, на Дунчесе матери Валентины, а матери Флины - на острове версты три от обители матери Тавифы» (Урало-Сибирский патерик, 2014: 174).

Здесь свидетельства Клавдии Ивановны расходятся с текстом патерика. Она указывает, что монастырь матушки Флены не был на острове, он был далеко от реки. Дальнейшие исследования и полевые выезды, надеемся, позволят уточнить расположение скитов.

Игуменьи управляли духовными делами. Подигуменья налаживала хозяйственное обустройство. Очень скоро такой подигуменьей в скиту Флены стала Елизавета Глухова, накрытая (принявшая монашеский постриг) как матушка Еванфия. Жили семьей, «мы между собою все одинаковы были». На каждую работу матушки и послушницы получали благословение. «Не только на каждую работу, на каждую секунду, чтобы она матушка знала куда идешь» (ПМА, 2018 г.).

Монастыри были немногочисленные.

«Тогда по десятку людей было в монастырях... Жили одной семьей» (ПМА, 2018 г.).

Не успели разрастись, настигло разорение.

В келье жили «...человек до десятка. Нас больше не было. И шибко мы были дружно жили. Ись 
нечего путем было. И никода мы ничо не обиделись. Работали и работали» (ПМА, 2018 г.). Отдыхали только ночью.

«На нас никако правило большое не давали. Мы рабочие люди, молодые. День работам, ночь спим без заботы. Утро стает, опять помолишься и тебе работу дадут, а ты работай» (ПМА, 2018 г.).

На молитве белицы не стояли, только монахини, надо было работать.

Послушницы выполняли все хозяйственные и тяжелые в том числе, работы: пилили ручными пилами лес, сеяли хлеб, ухаживали за огородом, ловили рыбу, лен сеяли и мяли, ткани полотно на кроснах. Собой из мира привезли только самые необходимые инструменты: пилы, лопаты, топоры, приходилось землю копать и мотыгами.

Мяса не было, скота не держали и на охоту не ходили.

«Накрытому человеку мышь нельзя убить, не то, что зверя. Такой закон» (ПМА, 2018 г.).

Рыба в реке была, но немного.

«Ловили рыбу на “морду”, особенно зимой в проруби. За один раз ловили от 5 до 10 кг. хариусов. Но соли то не было. А без соли то немного поешь» (ПМА, 2018 г.).

Ели рыбу больше в пост.

Тяжелый, изнурительный труд позволял выжить, прокормиться, не больше. Закономерный интерес современного горожанина о скуке или возможном детском желании попеть и поиграть был встречен искренним недоумением:

«Какая ты смешная. Прямо вот куда смешней того. Ты зачем шла? Еслиф пришла за этим, и человек напитанный етим, вот человеку говорят ты сам себе, еслиф тебе это надо то живи где тебе нужно».

Полуголодное существование не располагало к веселью, но и не приводило к унынию.

«Мы то полуголодные чо. Нам не до пения было... Исть то нечего было. Сколь посеем то не вырастет, то застынет...оставят на семена, нигде не возьмешь. Не запоешь. Кое-как жили, но не умирали. От голода никто не умер... Жили без соли. Сколько завезли соли - всю съели. И жили без соли. И без хлеба путем. Как заехали, сколько продуктов привезли, пшеницы или чо там, так с этим и жили» (ПМА, 2018 г.).

Верхнеенисейские скиты не представляли собой какого-либо исключительного явления. Они так же, как и в других местах старообрядческого расселения, были тесно связаны духовными и родственными узами с остальной округой. Большинство из них было трудно заметить со стороны реки, они были надежно укрыты, по-хозяйски обустроены. Старообрядцы ближайших мирских поселений так или иначе были включены в их хозяйственную жизнь, регулярно помогали продуктами. Хотя в основном скитская жизнь рассчитана на самообеспечение, отшельник должен кормиться плодами рук своих, однако таежному скиту в условиях сурового сибирского климата и престарелого в основном контингента обитателей трудно выжить абсолютно самостоятельно, без поддержки сельской округи (Стороженко, Татаринцева, 2016: 95).

Попыток уйти из монастыря никто не предпринимал и в силу вполне практических соображений, и по вполне осознаваемым конфессиональным мотивам.

«Куда мы пойдем умирать, это же нельзя. Если мы пойдем самовольно умирать. Примерно вот придумали бежать оттуда без благословления. Если бы умерли, мы бы погибли и не было бы никакого царствия небесного. Только мука вечная. Мы куда побежим? Мы же этим напитаны были. Если вы пойдете без благословления, и что с вами случится, все - вы пропали. Вот и все вот этим напитаны были» (ПМА, 2018 г.).

\footnotetext{
${ }^{1}$ Морда - рыболовная снасть, известная с глубокой древности у народов, ведущих традиционный образ жизни. Предназначена для ловли рыбы в реках у самого берега.
} 
Изоляция скитов была вполне осознанной стратегией сохранения конфессиональной чистоты. «Тогда в мир не ездили. Ни мир к нам, ни мы в мир. Никто никуда. Так и жили» (ПМА, 2018 г.). Молитва и труд - неизменные ценности, главные постулаты. Но на молитве послушники долго не стояли, только в воскресенье, считая службу 5-7 часов недолгой - «От этого не умрешь».

Граница сакрального и мирского мира у часовенных с одной стороны, условная, а с другой - достаточно жесткая (Покровский, 1975: 29). По приходу в монастырь «християнские» послушники и послушницы отправлялись на покаяние к о. Антонию. Клавдия Ивановна подчеркивала: «В скиту не говорят - “живем”, говорят - “гостим”, “приехали в гости”. Даже по 10-15 лет» (ПМА, 2016 г.).

Во время разгрома 1951 г. скит матушки Флены со всеми иконами, богослужебными книгами, утварью сожгли дотла. Всех членов ее духовной семьи привезли в скит отца Антония и отправили дальше со всеми арестованными на плотах до Енисея. Для бывшей послушницы, которая была «там (в скитах. - А. С.) все равно малый младенец. Вставай, утром ни чо не знаешь, чо тебе скажут» (ПМА, 2018), началась обычная мирская жизнь. Вырастила детей и внуков, похоронила мужа. Ее сестры - Лида, Иустина и Любовь также вышли замуж, родили детей. Дети и внуки Лиды живут в Верховье в Туве. Иустина и Любовь, похоронив мужей и поставив на ноги детей, ушли обратно в монастырь на Дубчес. Правда, накрыться до сих пор так и не решились - «ответственность то это знаш кака» (ПМА, 2018).

После освобождения в 1954 г. бывшие обитатели скитов разъехались по Сибири и скиты черноризцев Верховьев Малого Енисея рассматривались как возможный вариант возрождения обителей. Но последователи помнили завет о. Симеона - «...если кто уцелеет, возвращайтесь на Дубчес. Везде широко, здесь - в самый раз». Вернулись только накрытые молодые «ради нужды великой. Они погибнут в миру. Мирской жизнью начнут жить - и погибнут» (ПМА, 2016). Некоторые молодые матушки сожалели, что их так рано накрыли и им пришлось вернуться.

Сумевшие сбежать с плотов несколько человек, в том числе и Афанасий Герасимович Мурачев, почти сразу же стали восстанавливать и инфраструктуру скитов и книжность. В этом, возможно, заключается одна из причин сохранения за дубчесскими монастырями лидерской позиции среди прочих религиозных центров часовенных «пострадавших за веру». В 2010 г. сохранившиеся женские монастыри в Туве были вывезены отцом Сергием на Дубчес вместе со всей утварью, а также книгами, иконами. В настоящее время в Туве осталась одна матушка Авсияния, которая не пожелала уезжать.

Дубчесские монастыри практически не переставали быть духовными центрами не только для округи, но и всего социума часовенных в мире, включая тувинских. После разгрома для послушников бывших скитов не возникло ситуации неприкаянности. Они быстро разыскали своих родственников или подались в другие тайные поселения. Клавдия Ивановна уехала к матери, устроилась работать уборщицей в обычную среднюю школу в Ворогово. Семья очень быстро предпочла уехать в надежные поселения в Туву, в которых никто не стал задавать лишних вопросов, ведь переселялись хоть и к негласным, но к «своим». Среди единоверцев навсегда закрепилось о Клавдии Ивановне - «Она же с Дубчеса. Как раз там была». Это означает, что люди знают о ее пребывании в скитах до разгрома, уважают до сих пор, приходят за советом.

\section{Заключение}

Конфессиональное пространство часовенных не знает других границ, кроме сакральных. Собор там, где есть «свои» люди, родственники, единоверцы. Несмотря на кажущуюся разрозненность и удаленность их поселений, связи между ними никогда не разрываются. С начала XX столетия можно с уверенностью говорить о складывании единого конфессионального пространства часовенного согласия в Сибири, включившего в себя практически всю ее освоенную часть, но преимущественно территорию Тувы и Красноярского края. 
Потребность верующих «спасаться», желание уйти от коллективизации и других пагубных для души мирских явлений (светской школы, переписи, паспортизации, гражданской регистрации брака) приводили, несмотря на очевидные трудности и опасности, в движение непрерывный механизм старообрядческой конфессиональной миграции на огромных просторах Сибири в XX веке. Его инерция продолжается, находя выражение в новых запретах неприятие банковских карт, штрих-кода, мобильных телефонов, идеи чипирования (Проект документа ..., 2012: Электр. ресурс).

Потребность у часовенных в сохранении общего конфессионального пространства, сохранившееся совместное соборное обсуждение вызовов времени, поддержка чистоты конфессиональных брачных связей и, как следствие, сохранение семьи, общины, заинтересованной в существовании скитов как идеологических и духовных центров позволяет надеяться на дальнейшее развитие скитской традиции и даже, возможно, возрождение ее в Туве в обозримом будущем.

Конфессиональные связи часовенных убедительно прослеживаются именно на примере истории их скитской организации, родственно-землячески тесно связанной с мирской, крестьянской округой. Случайные люди в этой среде явление редкое. Соблюдение конфессиональной чистоты является важнейшей мировоззренческой установкой и одновременно залогом сохранения общины.

\section{СПИСОК ЛИТЕРАТУРЫ}

Дутчак, Е. Е. (2006) Путь в Беловодье (к вопросу о современных возможностях и перспективах изучения конфессиональных миграций) // Вестник РУДН. Серия История России. № 1 (6). C. 81-84.

Дутчак, Е. Е. (2007) Из «Вавилона» в «Беловодье» : адаптационные возможности таежных общин староверов-странников (вторая половина XIX - начало XXI в.) / под ред. В. В. Керова. Томск : Изд-во Томского университета. 414 с.

Дутчак, Е. Е. (2011) Скитская колонизация Западной Сибири : общее и особенное // Книга и литература в культурном пространстве эпох (XI-XX века) : сб. науч. статей / сост. и отв. ред. О. Н. Фокина, В. Н. Алексеев. Новосибирск : РИО ГПНТБ СО РАН. (Серия «Книга и литература»). 1056 с. С. $949-961$.

Журавель, О. Д. (2013) Предисловия в старообрядческой рукописной традиции // Гуманитарные науки в Сибири. № 4. С. 57-62.

Зольникова, Н. Д. (1998) Урало-сибирские староверы в первой половине XX.: Древние традиции в советское время // История русской духовной культуры в рукописном наследии XVI-XX вв. / отв. ред. Е. К. Ромодановская. Новосибирск : Наука ; Научно-издательский центр ОИГГС СО РАН. 316 с. (Археография и источниковедение Сибири. Вып. 18). С. 174-191.

Мамсик, Т. С. (1989) Хозяйственное освоение Южной Сибири: Механизмы формирования и функционирования агропромысловой структуры. Новосибирск : Наука. 240 с.

Мурачев, А. Г. (1999) История о Дупческом ските // Духовная литература староверов Востока России XVIII-XX вв. / под ред. Н. Н. Покровского. Новосибирск : Сибирский хронограф. 799 с. С. $289-292$.

Покровский, Н. Н. (1975) Крестьянский побег и традиции пустынножительства в Сибири XVIII в. // Крестьянство Сибири XVIII - начала XX вв. : Классовая борьба, общественное сознание и культура / отв. редактор Л. М. Горюшкин. Новосибирск : Наука. 219 с. С. 19-49.

Покровский, Н. Н. (1991) За страницей «Архипелага ГУЛАГ» // Новый мир. № 9. С. 77-90.

Покровский, Н. Н. (1992) Скитские биографии // Новый мир. № 8. С. 194-210.

Покровский, Н. Н., Зольникова, Н. Д. (2002) Староверы-часовенные на востоке России в XVIII-XX вв. : Проблемы творчества и общественного сознания. М. : Памятники исторической мысли. 471 с. 
Проект документа «О позиции Церкви в связи с появлением и перспективами развития новых технологий идентификации личности» (2012) [Электронный ресурс] // Русская православная церковь. 30 мая. URL: http://www.patriarchia.ru/db/text/2255365.html (дата обращения: 10.10.2018).

Стороженко, А. А. (2004) Старообрядчество Тувы во второй половине XIX - первой четверти XX в. : автореф. дисс. ... к. и. н. Красноярск. 26 с.

Стороженко, А. А. (2015) Конфессиональные миграции старообрядцев как канал межкультурного взаимодействия в Центральной Азии в XIX- начале XX в. // Старообрядчество: история и современность, местные традиции, русские и зарубежные связи: Материалы VI Международной научно-практической конференции / науч. ред. А. П. Майоров, отв. ред. С. В. Васильева. Улан-Удэ : Изд-во Бурятского гос. ун-та. 392 с. С. 130-136.

Стороженко, А. А., Татаринцева, М. П. (2016) Верхнеенисейские старообрядческие скиты в Туве: историческая реконструкция // Научные труды Тувинского государственного университета. Материалы ежегодной научно-практической конференции преподавателей, сотрудников и аспирантов ТувГУ, посвященной 65-летнему юбилею высшего педагогического образования в Туве и 95-летию становления Тувинской народной республики / отв. ред. У. В. Ондар. Кызыл : ФГБОУ ВО «Тувинский государственный университет». 228 с. С. 95-96.

Татаринцева, М. П., Стороженко, А. А. (2015) Старообрядцы Тувы: ретроспектива и современность. Saarbrucken: Lambert Academic Publishing. 137 с.

Татаринцева, М. П. (2006) Старообрядцы в Туве: историко-этнографический очерк. Новосибирск : Наука. 216 с.

Урало-Сибирский патерик: тексты и комментарии (2014) : в 3 т. / отв. ред. Н. Н. Покровский. М. : Языки славянской культуры. Кн. 1 (Т. 1-2). 464 с.

Дата поступления: 15.10.2018 г.

\section{REFERENCES}

Dutchak, E. E. (2006) Put' v Belovod'e (k voprosu o sovremennykh vozmozhnostiakh i perspektivakh izucheniia konfessional'nykh migratsii) [The way to Belovodye: On current opportunities and prospects of studying religiously motivated migrations)]. Vestnik RUDN. Seriia Istoriia Rossii, no. 1 (6), pp. 81-84. (In Russ.).

Dutchak, E. E. (2007) Iz «Vavilona» $v$ «Belovod'e» : adaptatsionnye vozmozhnosti taezhnykh obshchin staroverov-strannikov (vtoraia polovina XIX - nachalo XXI v.) [From "Babylon" to "Belovodye": adaptation opportunities in taiga communities of Old Believer Wanderers from the second half of the 19th to early 21st century)] / ed. by V. V. Kerova. Tomsk, Izd-vo Tomskogo universiteta. 414 p. (In Russ.).

Dutchak,E.E.(2011) Skitskaia kolonizatsiia Zapadnoi Sibiri : obshchee i osobennoe [Skete colonization of Western Siberia: the universal and the specific]. In: Kniga i literatura v kul'turnom prostranstve epokh (XI-XX veka) [Book and literature in the cultural space of 11th -20th centuries)] : a collection of articles / comp. and ed. by O. N. Fokina and V. N. Alekseev. Novosibirsk, RIO GPNTB SO RAN. (Issue «Book and Literature»). 1056 p. Pp. 949-961. (In Russ.).

Zhuravel', O.D. (2013) Predisloviia v staroobriadcheskoi rukopisnoi traditsii [Preface to the manuscript tradition of Old Believers]. Gumanitarnye nauki v Sibiri, no. 4, pp. 57-62. (In Russ.).

Zol'nikova, N. D. (1998) Uralo-sibirskie starovery v pervoi polovine XX.: Drevnie traditsii v sovetskoe vremia [The Ural-Siberian Old Believers in the first half of 20th century: Old traditions in Soviet times]. In: Istoriia russkoi dukhovnoi kul'tury v rukopisnom nasledii XVI-XX vv. [History of Russian spiritual culture in the manuscript heritage of 16th - 20th centuries] / ed. by E. K. Romodanovskaia. Novosibirsk,Nauka; Nauchno-izdatel'skii tsentr OIGGS SO RAN. 316 p. (Arkheografiia i istochnikovedenie Sibiri. Vol. 18). Pp. 174-191. (In Russ.). 
Mamsik, T. S. (1989) Khoziaistvennoe osvoenie Iuzhnoi Sibiri: Mekhanizmy formirovaniia i funktsionirovaniia agropromyslovoi struktury [Economic development of southern Siberia: Mechanisms of formation and functioning of agricultural system]. Novosibirsk, Nauka. 240 p. (In Russ.).

Murachev, A. G. (1999) Istoriia o Dupcheskom skite [The Story of the skit Duphaston]. In: Dukhovnaia literatura staroverov Vostoka Rossii XVIII-XX vv. [Spiritual literature of the Old Believers in Eastern Russia in the 18th-20th centuries] / ed. by N. N. Pokrovskii. Novosibirsk, Sibirskii khronograf. 799 p. Pp. 289-292. (In Russ.).

Pokrovskii, N. N. (1975) Krest'ianskii pobeg i traditsii pustynnozhitel'stva v Sibiri XVIII v. [Runaway peasants and the tradition of living in the wilderness in 18th century Siberia]. In: Krest'ianstvo Sibiri $X V I I I$ - nachala XX vv. : Klassovaia bor'ba, obshchestvennoe soznanie i kul'tura [The Peasantry of Siberia from the 18th to early 20th century: Class struggle, social consciousness and culture] / ed. by L. M. Goriushkin. Novosibirsk, Nauka. 219 p. Pp. 19-49. (In Russ.).

Pokrovskii, N. N. (1991) Za stranitsei «Arkhipelaga GULAG»[Behind the pages of the GULAG Archipelago]. Novyi mir, no. 9, pp. 77-90. (In Russ.).

Pokrovskii, N. N. (1992) Skitskie biografii [Skete biographies]. Novyi mir, no. 8, pp. 194-210. (In Russ.).

Pokrovskii, N. N. and Zol'nikova, N. D. (2002) Starovery-chasovennye na vostoke Rossii $v$ XVIII-XX vv. : Problemy tvorchestva i obshchestvennogo soznaniia [The 'chapel-going' Old Believers in the East of Russia in 18th -20th centuries: creativity and social consciousness]. Moscow, Pamiatniki istoricheskoi mysli. $471 \mathrm{p}$. (In Russ.).

Proekt dokumenta «O pozitsii Tserkvi v sviazi s poiavleniem i perspektivami razvitiia novykh tekhnologii identifikatsii lichnosti» (2012) [Draft document "On the position of the Church in connection with the emergence and prospects for the development of new technologies for identification of personality"]. Russkaia pravoslavnaia tserkov', May 30 [online] Available at: http://www.patriarchia.ru/ db/text/2255365.html (access date: 10.10.2018). (In Russ.).

Storozhenko, A. A. (2004) Staroobriadchestvo Tuvy vo vtoroi polovine XIX - pervoi chetverti XX v. [Old Believers of Tuva from the second half of 19th to the first quarter of 20th century] : Thesis of Diss.... Candidate of History. Krasnoiarsk. 26 p. (In Russ.).

Storozhenko, A. A. (2015) Konfessional'nye migratsii staroobriadtsev kak kanal mezhkul'turnogo vzaimodeistviia v Tsentral'noi Azii v XIX- nachale KhKh v. [Confessional migrations of Old Believers as a channel of intercultural interaction in 19th - early 20th century Central Asia]. In: Staroobriadchestvo: istoriia i sovremennost', mestnye traditsii, russkie i zarubezhnye sviazi [Old Belief: history and modernity, local traditions, Russian and foreign relations] : Proceedings of the 6th international conference / ed. by A. P. Maiorov and S. V. Vasil'ev. Ulan-Ude, Izd-vo Buriatskogo gos. un-ta. 392 p. Pp. 130-136. (In Russ.).

Storozhenko, A. A. and Tatarintseva, M. P. (2016) Verkhneeniseiskie staroobriadcheskie skity V Tuve: istoricheskaia rekonstruktsiia [Upper Yenisei Old Believers' monasteries in Tuva: a historical reconstruction]. In: Nauchnye trudy Tuvinskogo gosudarstvennogo universiteta [Research papers of Tuvan State University] : proceedings of the annual research conference of teachers, staff, and graduate students of TuvGU, dedicated to the 65th anniversary of higher pedagogical education in the Republic of Tuva and the 95th anniversary of the formation of the People's Republic of Tuva / ed. by U. V. Ondar. Kyzyl, FGBOU VO Tuvinskii gosudarstvennyi universitet. 228 p. Pp. 95-96. (In Russ.).

Tatarintseva, M. P. and Storozhenko, A. A. (2015) Staroobriadtsy Tuvy: retrospektiva i sovremennost' [Old Believers of Tuva: retrospective and modernity]. Saarbrucken, Lambert Academic Publishing. 137 p. (In Russ.).

Tatarintseva, M. P. (2006) Staroobriadtsy v Tuve: istoriko-etnograficheskii ocherk [Old Believers in Tuva: a historical and ethnographic essay]. Novosibirsk, Nauka. 216 p. (In Russ.).

Uralo-Sibirskii paterik [Ural-Siberian Patericon]: texts and comments (2014) : in 3 vols. / ed. by N. N. Pokrovskii. Moscow, Iazyki slavianskoi kul'tury. Book 1 (Vol. 1-2). 464 p. (In Russ.).

Submission date: 15.10 .2018$. 